J. Czerwik-Marcinkowska, W. Wróblewski, M. Gradziński, and B. Uher. Diatom species diversity and their ecological patterns on different substrates in two karstic streams in the Slovak karst. Journal of Cave and Karst Studies, v. 80, no. 3, p. 133-144. DOI:10.4311/2017MB0124

\title{
DIATOM SPECIES DIVERSITY AND THEIR ECOLOGICAL PATTERNS ON DIFFERENT SUBSTRATES IN TWO KARSTIC STREAMS IN THE SLOVAK KARST
}

\author{
Joanna Czerwik-Marcinkowska', c, Wojciech Wróblewski², Michal Gradziński², Bohuslav Uher³
}

\begin{abstract}
Many karstic streams are threatened both by anthropogenic and climate changes, but little is known about their algal biodiversity and conservation value, especially in the Slovak Karst. Diatom assemblages occurring on seven substrates, including stones, mud, submerged mosses and filamentous algae: Cladophora glomerata, Vaucheria sp., Ulothrix zonata, Spirogyra sp. in two nameless karstic streams in the Krásnohorská Dlhá Lúka Village and the Gombasek Cottage Settlement (the Slavec Village) in the Košice Region of central-eastern Slovakia (the Silická Plateau) were studied. A total of 124 diatom taxa were found at four sites, where epilithic and epiphytic diatom assemblages dominated. Both species' richness and Shannon-Wiener indices showed congruent biotic integrity. The dominant taxa were alkaliphilous, halophobous-oligohalobous, requiring xeno-oligosaprobic and oligotrophic waters. Diatoms include: Diploneis krammeri, Encyonema ventricosum, Gomphonema acuminatum, Gyrosigma attenuatum, Navicula tripunctata, and Paraplaconeis cracoviensis. The latter species is a new report for Slovakia, reflecting the calcareous, geological nature of the Silická Plateau (the Slovak Karst). Diatom assemblages in two karstic streams consisted mainly of small-celled species of Achnanthidium, Amphora, Caloneis, Planothidium, and Stauroneis. Our results showed that the diatom assemblages were mostly structured by environmental factors of calcium and $\mathrm{pH}$ gradients, confirmed by canonical variates analysis (CVA) and Monte Carlo permutation tests. However, unique spatial and biological gradients, specific to different guilds related to each other, were also evident. The Slovak karstic streams should be especially protected and regularly monitored.
\end{abstract}

\section{Introduction}

Karstic formations are extremely complex, and, due to a number of geological and hydrological characteristics, can be included among the most fragile and vulnerable environments in the world (Brinkmann and Parise, 2012). Complexity of karst is expressed by the enormous variations existing in different karst regions (White, 1988). Karstic areas cover 10 to $20 \%$ of the earth's surface and provide 40 to $50 \%$ of the world's drinking water (Ford and Williams, 2007), and it requires a specific approach to mitigate negative human impacts and allow sustainable development. Karstic streams are considered among the most sensitive, water-dependent ecosystems, and their ecological value is important as strategic water sources. Karst is a landscape that results from the chemical weathering and collapse of carbonate rocks (limestone, dolomite, and gypsum), which creates such features as sinkholes, caves, and underground drainage. The Slovak Karst area located in eastern Slovakia is a typical upland karst, consisting of several karst plateaus (Gradziński et al., 2013). These plateau tops and some slopes are partly covered by deciduous forests, and south-facing, steep, partly rocky slopes are occupied by xerothermic grasslands and bushes. The karstic waters from the Slovak Karst are drained by the autochthonous and allochthonous rivers, streams, and springs located in the non-karstic region of the adjacent mountains. Karstic streams are widespread in European regions, where Paleozoic, Mesozoic and Cenozoic limestone formations are subject to present-day karstification (Arp et al., 2010).

The Slovak Karst is a hotspot area for biodiversity, representing specific environments; it is included in the URL UNESCO World Heritage List. Karst regions interact with the environment to produce complex ecosystems supporting specialist plants, animals, and microorganisms. In karstic streams, $\mathrm{CO}_{2}$ degassing drives the increase of calcite saturation to maximum values of approximately 10 -fold, independent from the initial $\mathrm{Ca}^{2+}$-alkalinity ratio. Diatoms are potentially involved in $\mathrm{CaCO}_{3}$ mineral nucleation via exopolymers and/or alternating $\mathrm{CaCO}_{3}$ mineral saturation within microenvironments. Diatoms, by far, are the most dominant eukaryotic microalgal group in karst water streams (Arp et al., 2010). According to Smol and Stoermer (2015), these microhabitats are the most interesting aquatic environments for the study of algae, especially diatoms. They are considered as useful indicators of environmental quality and reflect the ecological integrity of stream habitats. Diatoms are pioneering, autotrophic colonizers in river and stream ecosystems, and they are the main element used for monitoring studies due to their rapid assemblages' response to stress (Potapova et al., 2004; Bellinger et al., 2006). Diatom assemblages are adapted to the local environmental conditions

\footnotetext{
1Department of Botany, Institute of Biology, Jan Kochanowski University, Świętokrzyska 15, 25-420 Kielce, Poland ${ }^{2}$ Institute of Geological Sciences, Jagiellonian University, Oleandry 2a, 30-063 Kraków, Poland

${ }^{3}$ Department of Microbiology, Immunobiology and Genetics, Max F. Perutz Laboratories, University of Vienne, Dr. Bohr Gasse 9, A-1030 Vienna, Austria

cCorresponding author: marcinko@kielce.com.pl
} 
in relation to changes in water residence time and to the variations in the ionic content in water, due to flow volume variations (Aboal et al., 1996).

Streams may flow all year round or only intermittently due to desiccation, freezing, or karst phenomena, and they present unique, but understudied, habitats. The karst water streams often sink, particularly on substrates of loose moraine deposits, and reappear again after a certain distance (Kawecka, 2012). Thus, the study of diatoms, both in typical and karstic streams, are an important element of monitoring and assessment programs in countries around Europe. Diatom assemblages are not only useful for an assessment of the relative role of environmental and spatial factors (Heino et al., 2010), but also for assessing the relevance of biological species sorting (Arp et al., 2010).

Consequently, the aim of the present study was to evaluate changes in the structure and species richness of diatoms occurring in karst water streams in middle-eastern Slovakia (the Silická Plateau), and their relationship with environmental variables that influence the diatom assemblages. This study describes the biodiversity of epilithic and epiphytic diatom assemblages, with particular interest in the significance of such habitats for conservation. However, there is the likelihood of underestimating local control and overestimating regional control of karstic stream assemblages. More specifically, we predicted that different diatoms indicate a similar, strong response to the environmental gradient, and a similar, weak response to the spatial gradient, due to the small study area, and different responses to the biotic gradient, due to differences in ecologically-sensitive species.

\section{Materials and Methods}

Sampling Sites and Procedures - Four water sites were sampled for physical, chemical, and biological variables in September 2014: three (GP 4.4, GP 4.7, and GP 4.8) from a nameless stream in the Gombasek Cottage Settlement (the Slavec Village) and one (KP 3.5) in the Krásnohorská Dlhá Lúka Village. The two nameless streams belong to the Čremošná tributary (Krásnohorská Dlhá Lúka; N 48³7'02.29" E 20³5'14.97") and to the Slaná tributary (Gombasek; N 483'46.21" E $\left.20^{\circ} 27^{\prime} 57.57^{\prime \prime}\right)$. They are situated in headwater streams draining the Silická Plateau (in Slovak; Silická Planina), which is an extensive karst massif, built predominantly of carbonate rocks (Fig. 1). Presently, tufa precipitations are situated at both studied sites (Kilík, 2008; Gradziński et al., 2013), forming barrages and intervening pools (Figs 2-3), colonized by cyanobacteria, coccoid and filamentous algae, and mosses.

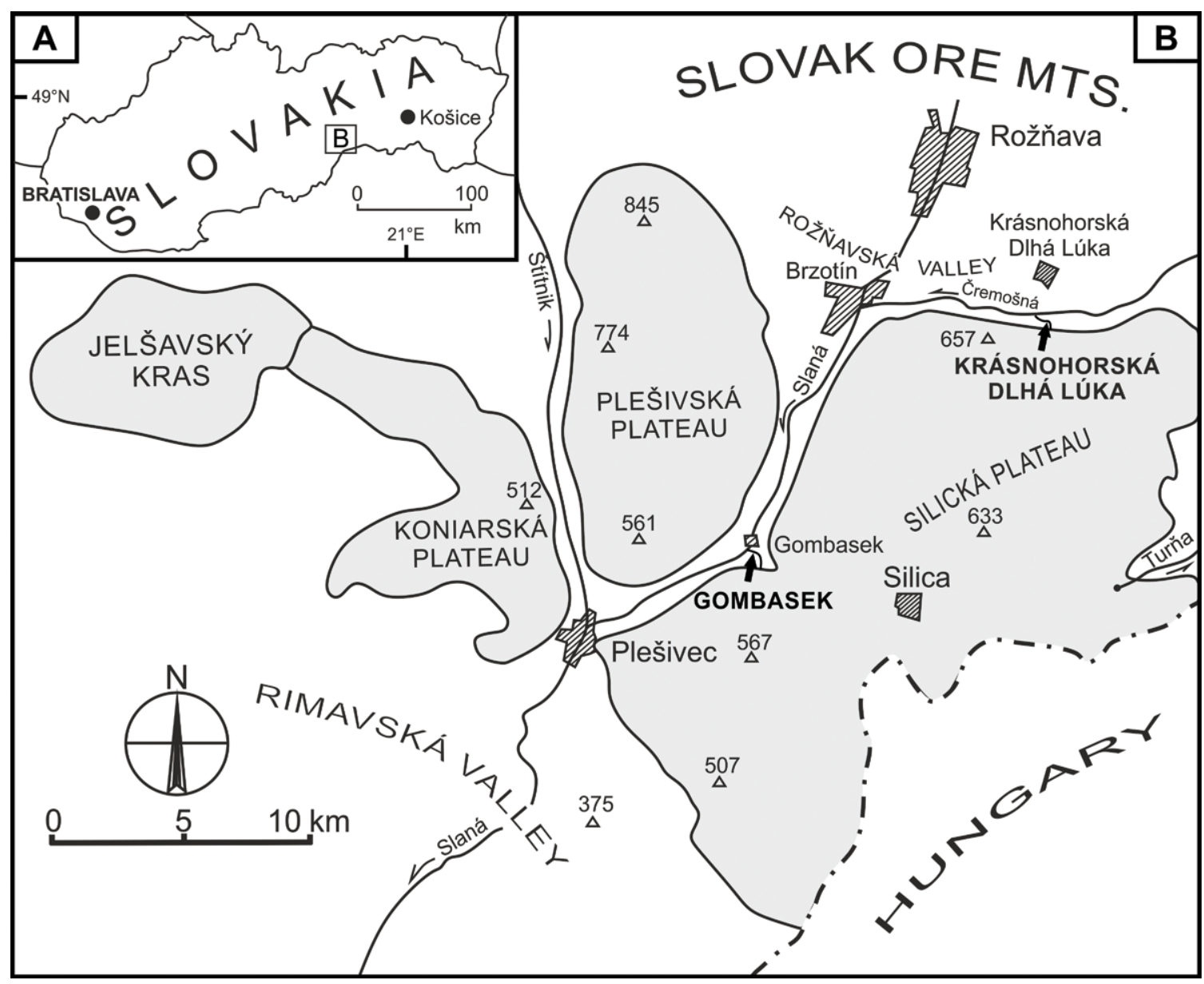

Figure 1. Sampling sites located in the Slovak Karst. A - The map of Slovakia with reference points, B The collection sites (two streams) are indicated by black arrows. 


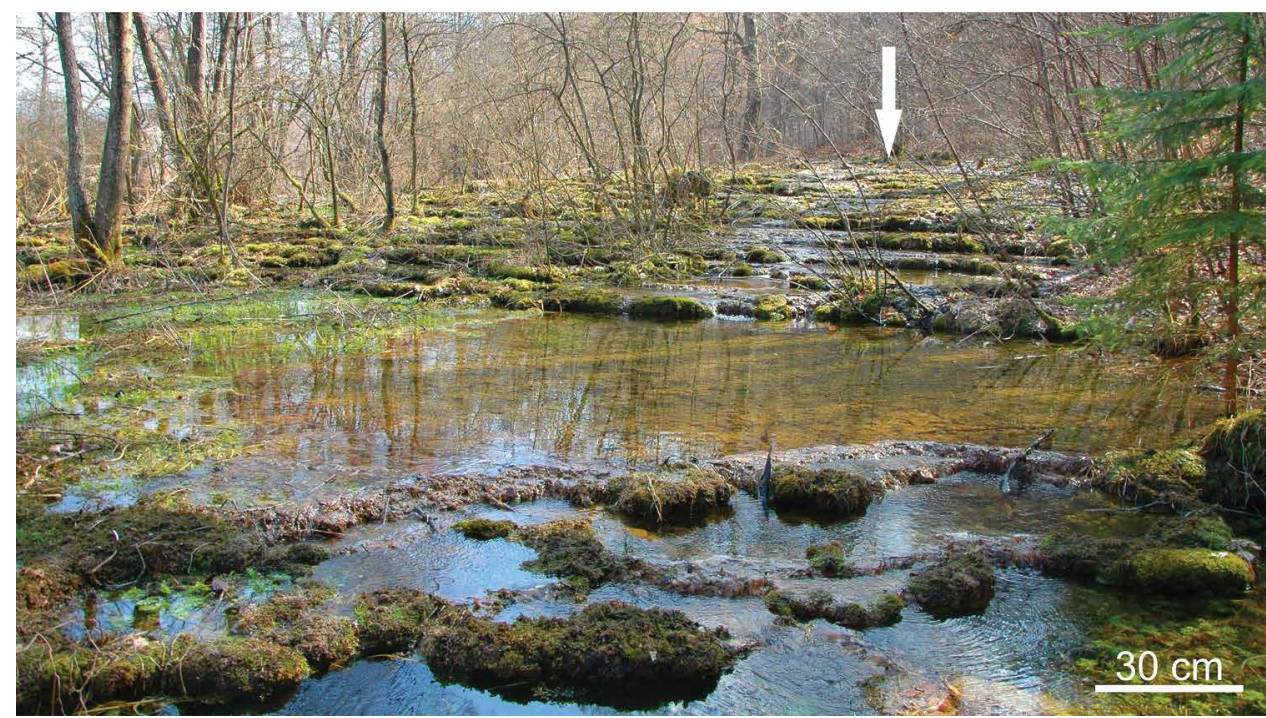

Figure 2. Barrages and pools in Krásnohorská Dlhá Lúka Village, arrow indicates sampling site.

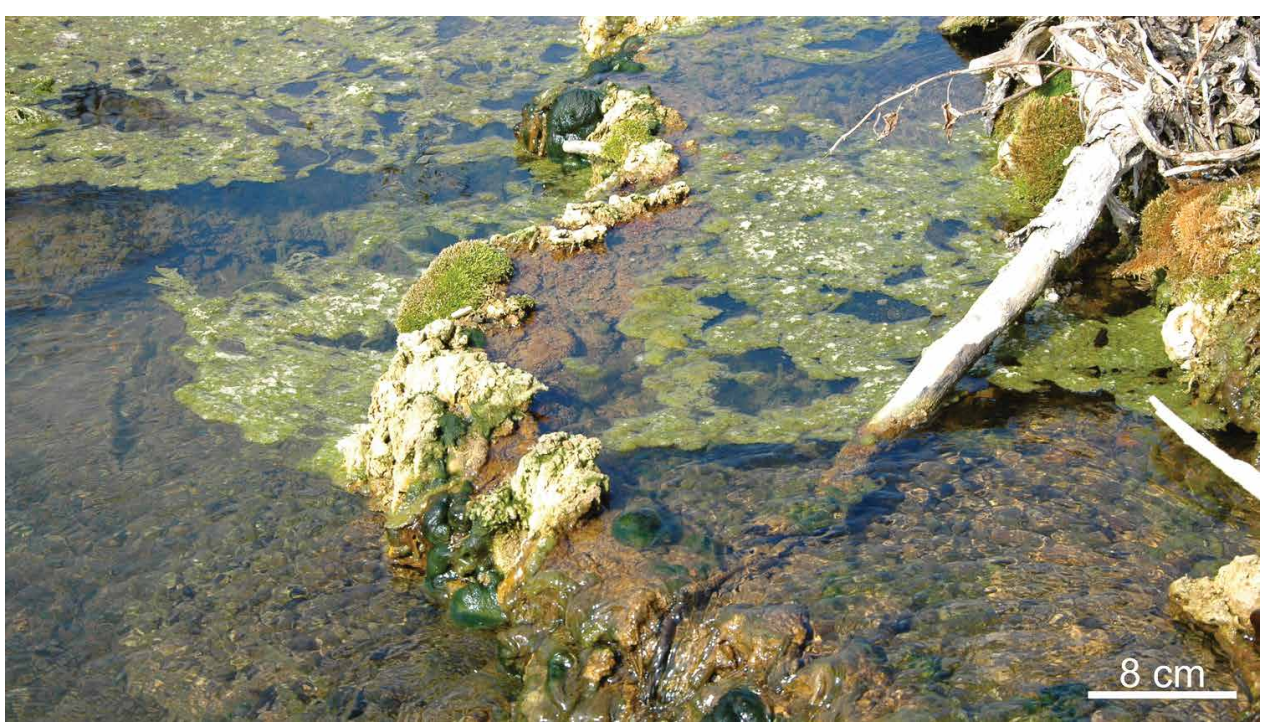

Figure 3. Barrage colonized by cyanobacteria, algae, and mosses, Gombasek Cottage Settlement site.

The the scraped materials. The collected samples were preserved by adding commercially avalable, neutral-

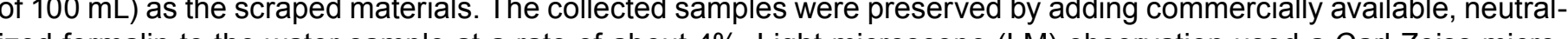
ized formalin to the water sample at a rate of about $4 \%$. Light microscope (LM) observation used a Carl Zeiss microscope, Jenamed 2, whereas micrographs were made using a Nikon E 600 Eclipse microscope. The relative abundance of particular taxa and the richness of the species assemblages were estimated on the basis of at least 200 diatoms per sample. For SEM, 10-20 mL aliquots of sample were digested with concentrated $\mathrm{H}_{2} \mathrm{O}_{2}$ and heated for 24 hours in a sand bath. The sample was allowed to cool and settle and $80-90 \%$ of the supernatant was removed by vacuum aspiration. Coating with platinum was accomplished using the BAL-TECMED 020 Modular High Vacuum System for 30 $\mathrm{s}$ at $100 \mathrm{~mA}$. Micrographs were digitally processed and plates containing LM and SEM images were prepared using Photoshop CS3 and CorelDRAW X5. Diatoms were identified according to Krammer and Lange-Bertalot (1986, 1991, 2004), Krammer (2002), Lange-Bertalot (2001) and Lange-Bertalot and Wojtal (2014). The diatom ecology, preferences of the species with respect to $\mathrm{pH}$, moisture, and trophy were determined by Van Dam et al. (1994), and the diversity of assemblages was quantified using the $\mathrm{H}^{7}$ (Shannon-Wiener diversity index).

\section{Statistical Analysis}

Data are presented in a three-step scale, where one means species encountered sporadically, two means frequently, and three is a dominant species, and the data were used to calculate $\mathrm{H}^{7}$ (Shannon-Wiener diversity index). The diversity $t$ test of difference significance between the diversity indexes of studied habitats was performed. Diatom 
Table 1. Average of physico-chemical waters parameters in study sites KP and GP during observation period 2011-2013.

\begin{tabular}{|c|c|c|c|c|c|c|c|c|c|c|c|c|c|}
\hline Site & $\mathrm{pH}$ & $E C^{*}$ & $\mathrm{tH}_{2} \mathrm{O}$ & $\mathbf{Q}^{* *}$ & $\mathrm{Ca}$ & $\mathbf{M g}$ & $\mathrm{Na}$ & $\mathrm{K}$ & $\mathrm{HCO}_{3}$ & $\mathrm{SO}_{4}$ & $\mathrm{Cl}$ & $\mathrm{SiO}_{2}$ & TDS† \\
\hline & & {$[\mu \mathrm{S} / \mathrm{cm}]$} & {$\left[{ }^{\circ} \mathrm{C}\right]$} & {$[\mathrm{L} / \mathrm{s}]$} & {$[\mathrm{mg} / \mathrm{L}]$} & {$[\mathrm{mg} / \mathrm{L}]$} & [mg/L] & {$[\mathrm{mg} / \mathrm{L}]$} & [mg/L] & [mg/L] & {$[\mathrm{mg} / \mathrm{L}]$} & [mg/L] & {$[\mathrm{mg} / \mathrm{L}]$} \\
\hline KP & 7.82 & 617 & 9.4 & 179 & 125.14 & 10.37 & 1.19 & 0.65 & 368.35 & 51.77 & 3.59 & 4.90 & 559 \\
\hline GP & 8.10 & 608 & 8.4 & 25 & 125.34 & 8.50 & 3.93 & 4.91 & 374.86 & 30.85 & 10.38 & 30.99 & 567 \\
\hline
\end{tabular}

${ }^{*} \mathrm{EC}$ - electric conductivity

** $Q$ - discharge

† TDS - total dissolved solids

assemblages and their relation to environmental variables were examined using principal component analysis (PCA) in PAST, ver. 3.0 (Hammer et al., 2001). Data were analyzed and the factors differentiating studied habitats were determined. Diatoms were subjected to the correspondence variate analysis (CVA), and this analysis was repeated. The CVA analysis was used to determine if there was a difference between the sites in terms of diatom species composition, whereas the second analysis determined whether the correlation between the diatoms occurrence and the kind of substrate is significant. In the first, CVA analysis with environmental data represent a properly constructed file in which information about studied positions was coded. In the second analysis, the substrates of four studied sites was encoded. The file of the species in both cases was the same with the diatom data in a three-point scale. Monte Carlo permutation tests were used to select a set of environmental variables that relate best with species assemblages. The diagram ordination was illustrated by principal component analysis (PCA), where the diatoms' species composition is related to the sites; if the site point is closer to the species point, then there is greater participation of the species in the sample. In the diagrams of the PCA analysis, the environmental variables were presented as the vectors, the sites or substrates as the points, and the species as the triangles. A location of the point near the vector of a given variable indicates that this species prefers the conditions set precisely by this variable. Both of the above, multivariate analysis ordinations (PCA, CVA) were performed using the Canoco 4.5 software (ter Braak \& Šmilauer, 2002). The PCA indirect ordination was presented as the diagram of diatom species and their appropriate genera.

\section{Results}

A total of 124 diatom species belonging to 39 genera were found in two nameless karst water streams in the Krásnohorská Dlhá Lúka Village and in the Gombasek Cottage Settlement in central-eastern Slovakia (the Silická Plateau). The vast majority of the diatoms were typically epilithic or epiphytic forms, which developed on the stone surfaces, mud, filamentous algae (Cladophora glomerata, Vaucheria sp., Ulothrix zonata, Spirogyra sp.), and submerged mosses (Brachythecium rivulare, Polytrichum strictum, and Scapania undulata). Diatom assemblages were dominated by Gomphonema acuminatum (25\%), Cocconeis placentula (12\%), and Frustulia vulgaris (10\%) and are illustrated by LM micrographs. The most frequently encountered diatoms were members of the genera Pinnularia (10 species), followed by Gomphonema (8), Eunotia (7), Neidium (7), Nitzschia (6), and Staurosirella (5). Only five species appeared in four sampling sites: Paraplaconeis cracoviensis, Navicula tripunctata, Gomphonema acuminatum, Gyrosigma attenuatum and Amphora ovalis.

The rare species Paraplaconeis cracoviensis (Fig. 4), which, until now, was only identified in the Kobylanka stream ca. $30 \mathrm{~km}$ northwest of Kraków in Poland (sample 6 found by Lange-Bertalot and Wojtal, 2014) as a new species for science was described. This species is characteristic for alkaline springs and streams, mesotrophic, oligo- $\beta$-mesosaprobic, calcium-rich waters with moderate-high conductivity. It is also a species occurring in two studied, nameless karst water streams in the Silická Plateau (Slovak Karst).

The most interesting taxa from the ecological point of view were: Luticola nivalis from waters with the highest values of calcium (125.34 mg/L) and $\mathrm{SiO}_{2}(30.99 \mathrm{mg} / \mathrm{L})$, Encyonema ventricosum and Gomphonema truncatum from streams with water of high conductivity.

The frequency occurrence of every recorded taxa was based on the observation of four samples from each site (Table 2). The number of diatom species varied depending on the type of microhabitat substrate specificity; on stones there were 62 species, whereas nearly twice more were on mosses (119). The Shannon-diversity index was 3.0 for stones and 4.6 for mosses. Both microhabitats contained abundant populations of Cyclotella distinguenda, Cymatopleura elliptica, and Gomphonema truncatum, occurring on stones and accompanied by Cocconeis pediculus Ehr. Whereas on mosses, there were large populations of Diploneis krammeri, Gyrosigma attenuatum and Amphora ovalis.

The highest species diversity was in the sampling sites GP4.8 and GP4.4, and the lowest on KP3.5 and GP4.7. Site GP4.4 was the most atypical, and characterized by the absence of small species and the presence of many large-size diatoms: Hantzschia calcifuga, Gyrosigma attenuatum, Stauroneis phoenicenteron and Frustulia vulgaris. Green alga Cladophora glomerata provides a suitable substrate for colonization by following diatoms: Cymatopleura distinguenda, 

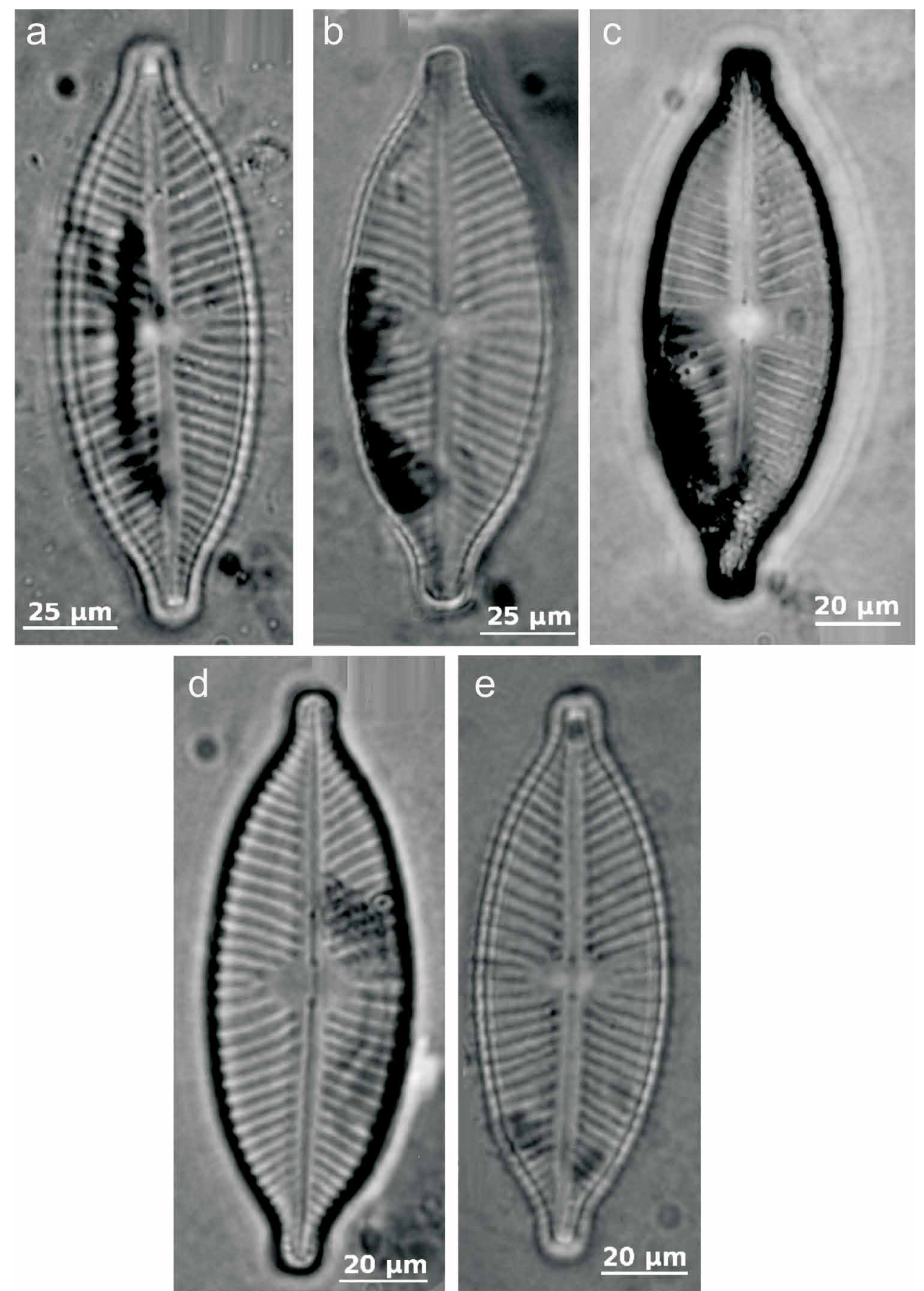

Figure 4, a,b,c,d,e Paraplaconeis cracoviensis Lange-Bertalot and Wojtal, sp. nov. LM. Light micrographs (LM) of valves from two nameless streams (the Krásnohorská Dlhá Lúka Village and the Gombasek Cottage Settlement). LM views of several specimens showing variation in valve size and shape.
C. elliptica, C. solea and Frustulia vulgaris. While xanthophyte Vaucheria sp. was substrate for species: Achnanthidium minutissimum, Nitzschia commutata and Denticula tenuis. Other common taxa included: Navicula tripunctata (on mud), Hantzschia calcifuge (on filamentous algae) and UInaria biceps (both on stones and mosses), observed in karst water streams, characteristic for waters neutral to alkaline $\mathrm{pH}$. Among dominating species from the genus Achnantidium, e.g. Achnanthidium minutissimum prefers waters with circumneutral $\mathrm{pH}$, whereas $A$. pyrenaicum indicated the alkaline waters. Gomphonema pumilum, recorded in the material collected from thalli of Vaucheria sp., showed high vitality in environments ranging from mesotrophy to eutrophy.

The Shannon-Wiener diversity index (Fig. 5) was calculated for diatoms, and its highest value $H^{\prime}$ was recorded for site GP $4.8\left(H^{\prime}\right.$ $=4.25)$, and the lowest for KP 3.5 $\left(H^{\prime}=4.06\right)$. This analysis showed that the significance of the correlation data depends on the substrate type, e.g. Vaucheria sp. thalli. The intermediary ordination analysis for the complete data from the four sampling sites was performed. It was concluded that the gradient along first ordination axis is connected with Eunotia implicata, E. intermedia, E. minor. On the other side of the axis were the species preferring a different type of substrate. PCA analysis showed a relation between diatom assemblages at each site and selected environmental variables. The first ordination axis accounted for $37.7 \%$ of the variation in diatom species composition among sites, and the second ordination axis accounted for $23.5 \%$ (Fig. 6). Discrimination analysis was done to determine the species differences between four sampling sites. The results analysis showed that these sites do not differ in terms of diatom species composition. None of the canonical axes were significant in the presented model. Therefore, the analogical CVA analysis was done for the same diatom data, but the substrate was taken into account (Fig. 7). The analysis showed that the significance of the correlation data depends on the substrate type, e.g. Vaucheria sp. thalli. The species that preferred this type of substrate were: Neidium affine, Gomphonema acuminatum, G. brebissonii and G. truncatum. This dependent variable was explained by $4.8 \%$, the total data of the variance (Fig. 8). Correlations of remaining substrata with species turned out to be insignificant. 


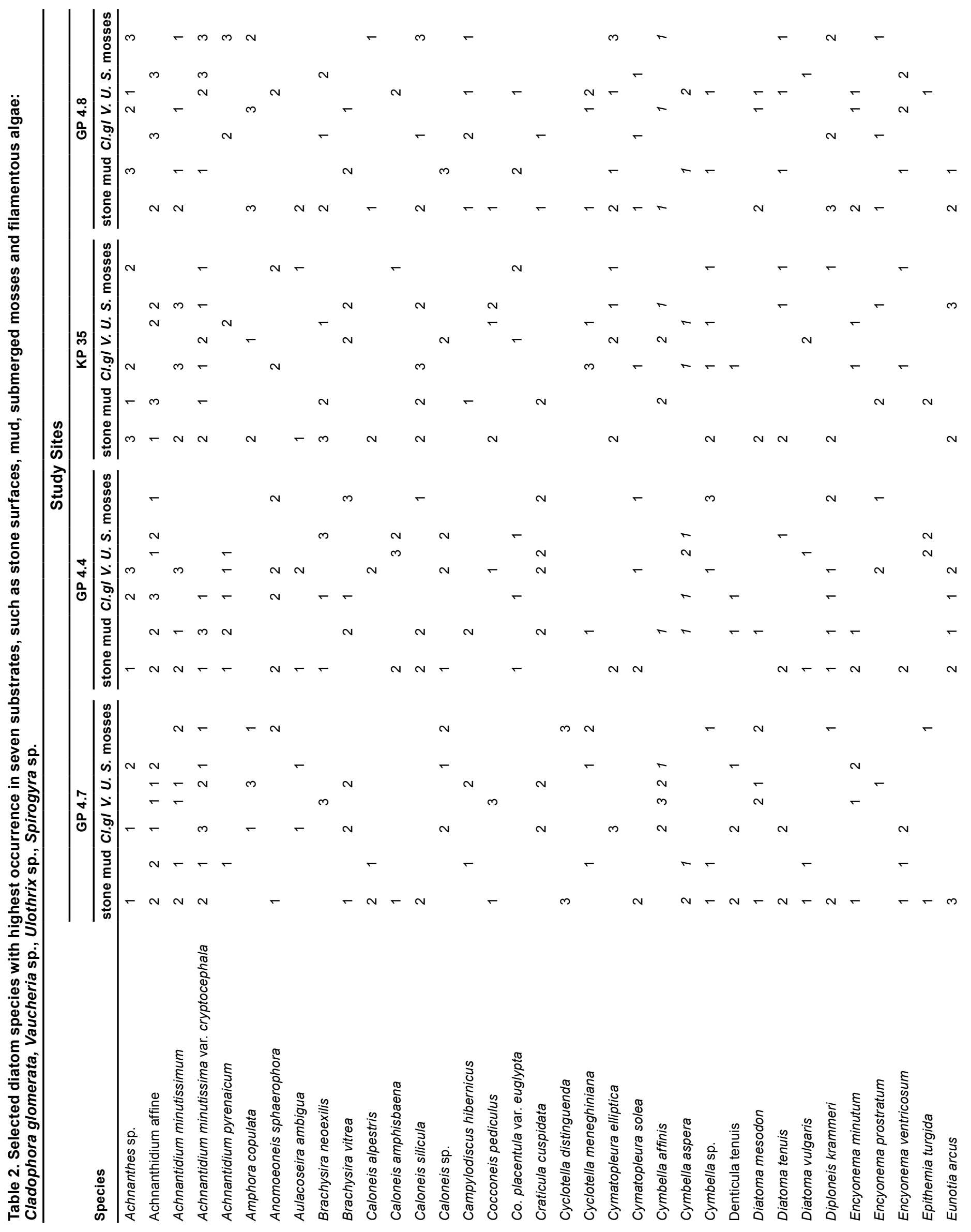




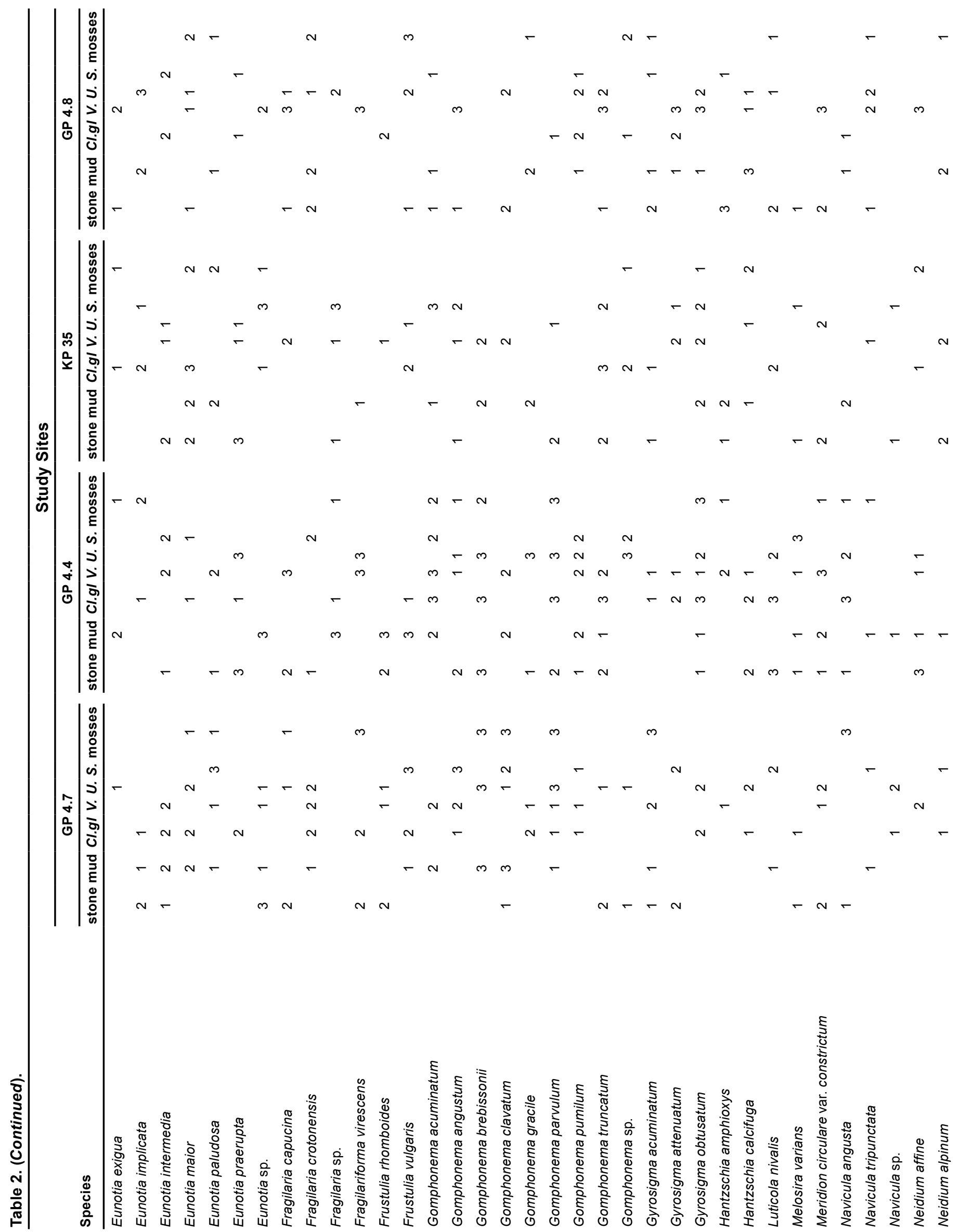




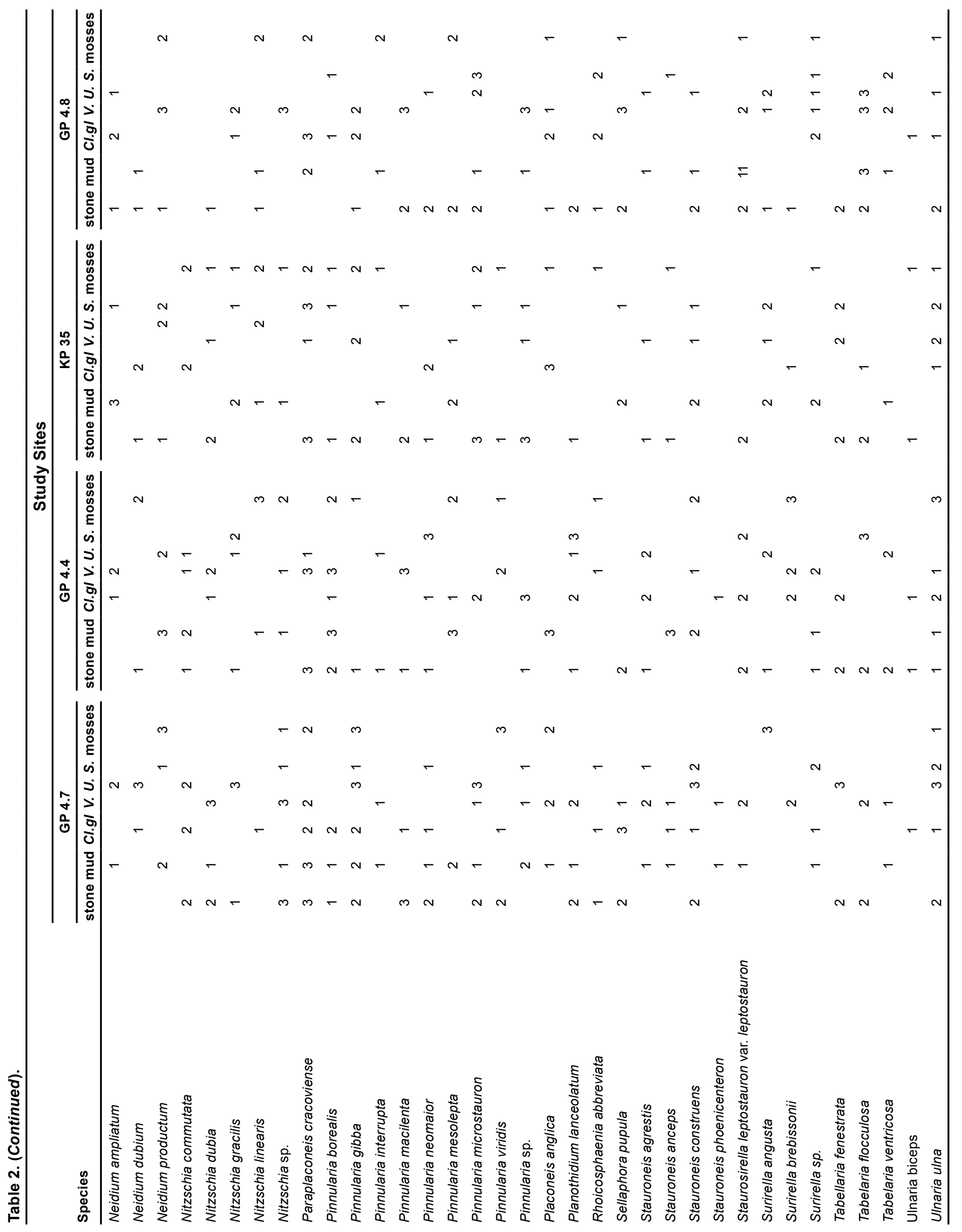



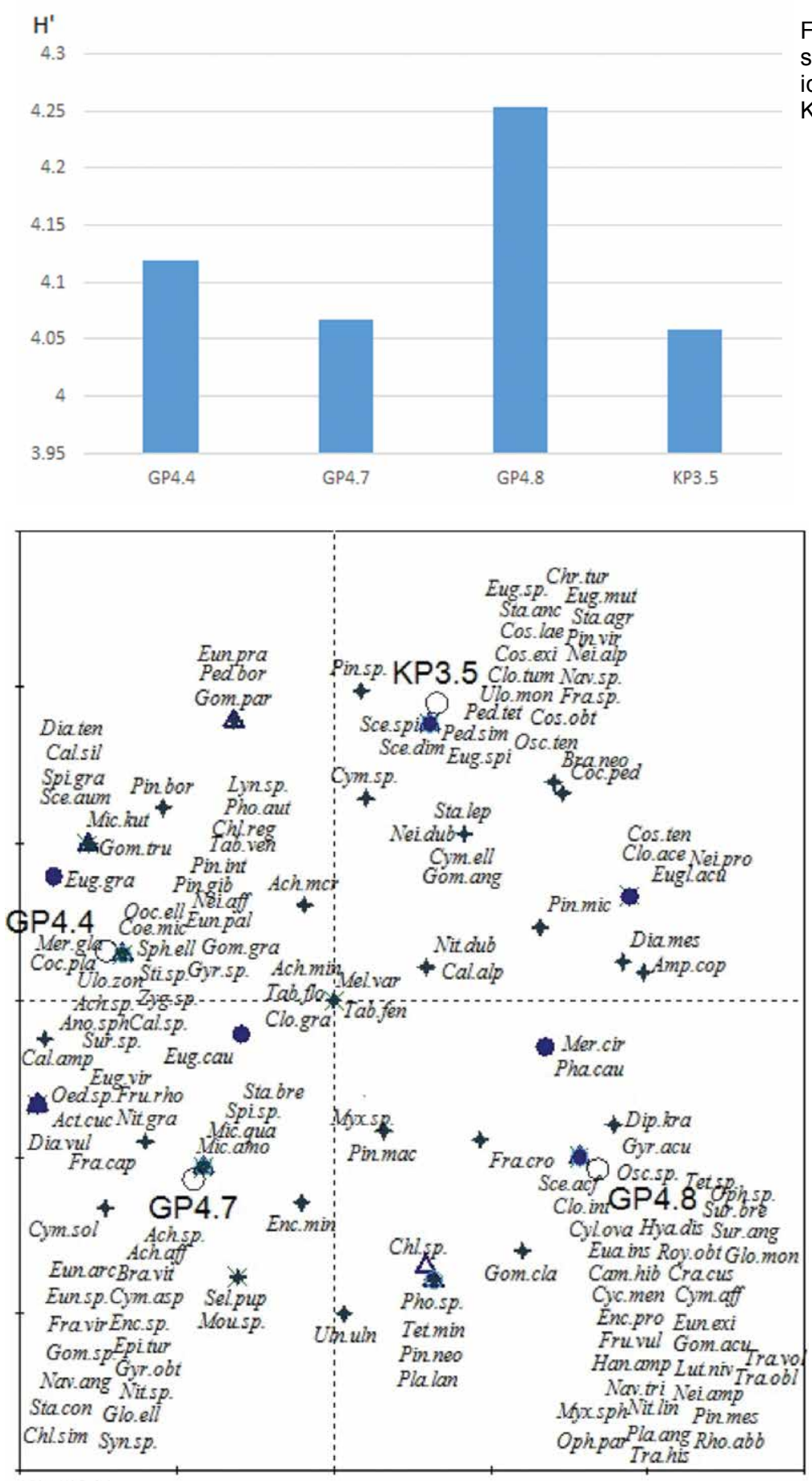

SPECIES

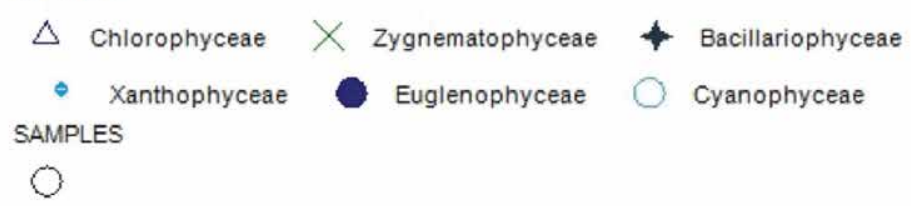

Figure 5. The Shannon diversity index for diatoms from four sites (GP4.4, GP4.7, GP4.8, KP3.5). The only statistically significant difference was between sites KP3.5 and GP4.8 $(p<0.005$, Kruskal-Wallis test).
Figure 6. Principal component analysis (PCA) for the diatom assemblages in four sites (GP4.4, GP4.7, GP4.8, KP3.5). The first ordination axis accounted for $37.7 \%$ of the variation in diatom species composition among sites. Abbreviations of species names in Fig. 6 consist of three letters of a generic name and three letters of a species name.

Abbreviations of species names: Achnanthes sp. (Ach. sp.); Achnanthidium affine (Ach. aff.); Achn. 'minutissimum (Ach. min.); Achn. minutissima var. cryptocephala (Ach. cry.); Achn. pyrenaicum (Ach. pyr.); Amphora copulata (Amp. cop.); Anomoeoneis sphaerophora (Ano. sph.); Aulacoseira ambigua (Aul. amb.); Brachysira neoexilis (Bra. neo.); Brachysira vitrea (Bra. vit.); Caloneis alpestris (Cal. alp.); Caloneis amphisbaena (Cal. amp.); Caloneis silicula (Cal. sil.); Caloneis sp. (Cal. sp.); Campylodiscus hibernicus (Cam. hib.); Cocconeis pediculus (Coc. ped.); Cocconeis placentula var. euglypta (Coc. eug.); Craticula cuspidata (Cra. cus.); Cyclotella distinguenda (Cyc. dis.); Cyclotella meneghiniana (Cyc. men.); Cymatopleura elliptica (Cyc. ell.); Cyclotella solea (Cyc. sol.); Cymbella affinis (Cym. aff.); Cymbella aspera (Cym. asp.); Cymbella sp. (Cym. sp.); Denticula tenuis (Den. ten.); Diatoma mesodon (Dia. mes.); Diatoma tenuis (Dia. ten.); Diatoma vulgaris (Dia. vul.); Diploneis krammeri (Dip. kra.); Encyonema minutum (Enc. min.); Encyonema prostratum (Enc. pro.); Encyonema ventricosum (Enc. ven.); Epithemia turgida (Epi. tur.); Eunotia arcus (Eun. arc.); Eunotia exigua (Eun. exi.); Eunotia implicata (Eun. imp.); Eunotia intermedia (Eun. int.); Eunotia maior (Eun. mai.); Eunotia paludosa (Eun. pal.); Eunotia praerupta (Eun. pre.); Eunoti sp. (Eun. sp.); Fragilaria capucina (Fra. cap.); Fragilaria crotonensis (Fra. cro.); Fragilaria sp. (Fra. sp.); Fragilariformis virescens (Fra. vir.); Frustulia rhomboides (Fru. rho.); Frustulia vulgaris (Fru. vul.); Gomphonema acuminatum (Gom. acu.); Gomphonema angustum (Gom. ang.); Gomphonema brebissonii (Gom. bre.); Gomphonema clavatum (Gom. cla.); Gomphonema gracile (Gom. gra.); Gomphonema parvulum (Gom. par.); Gomphonema pumilum (Gom. pum.); Gomphonema truncatum (Gom. tru.); Gomphonema sp. (Gom. sp.); Gyrosigma acuminatum (Gyr. acu.); Gyrosigma attenuatum (Gyr. att.); Gyrosigma obtusatum (Gyr. obt.); Hantzschia amphioxys (Han. amp.); Hantzschia calcifuga (Han. cal.); Luticola nivalis (Lut. niv.); Melosira varians (Mel. var.); Meridion circulare var. constrictum (Mer. cir.); Navicula angusta (Nav. ang.); Navicula tripunctata (Nav. tri.); Navicula sp. (Nav. sp.); Neidium affine (Nei. aff.); Neidium alpinum (Nei. alp.); Neidium ampliatum (Nei. aml.); Neidium dubium (Nei. dub.); Neidium productum (Nei. prod.); Nitzschia commutata (Nit. com.); Nitzschia dubia (Nit. dub.); Nitzschia gracilis (Nit. grac.); Nitzschia linearis (Nit. lin.); Nitzschia sp. (Nit. sp.); Paraplaconeis cracoviense (Par. cra.); Pinnularia borealis (Pin. bor.); Pinnularia gibba (Pin. gib.); Pinnularia interrupta (Pin. int.); Pinnularia macilenta (Pin. mac.); Pinnularia neomajor (Pin. neo.); Pinnularia mesolepta (Pin. mes.); Pinnularia microstauron (Pin. mic.); Pinnularia viridis (Pin. vir.); Pinnularia sp. (Pin. sp.); Placoneis anglica (Pla. ang.); Planothidium lanceolatum (Pla. lan.); Rhoicosphaenia abbreviata (Rho. abb.); Selaphora pupula (Sel. pup.); Stauroneis agrestis (Sta. agr.); Stauroneis anceps (Sta. anc.); Stauroneis construens (Sta. con.); Stauroneis phoenicenteron (Sta. pho.); Staurosirella leptostauron var. leptostauron (Sta. lep.); Surirella angusta (Sur. ang.); Surirella brebissonii (Sur. bre.); Surirella sp. (Sur. sp.); Tabellaria fenestrata (Tab. fen.); Tabellaria flocculosa (Tab. flo.); Tabelaria ventricosa (Tab. ven.); Ulnaria biceps (Uln. bic.); Ulnaria ulna (Uln. uln.). 

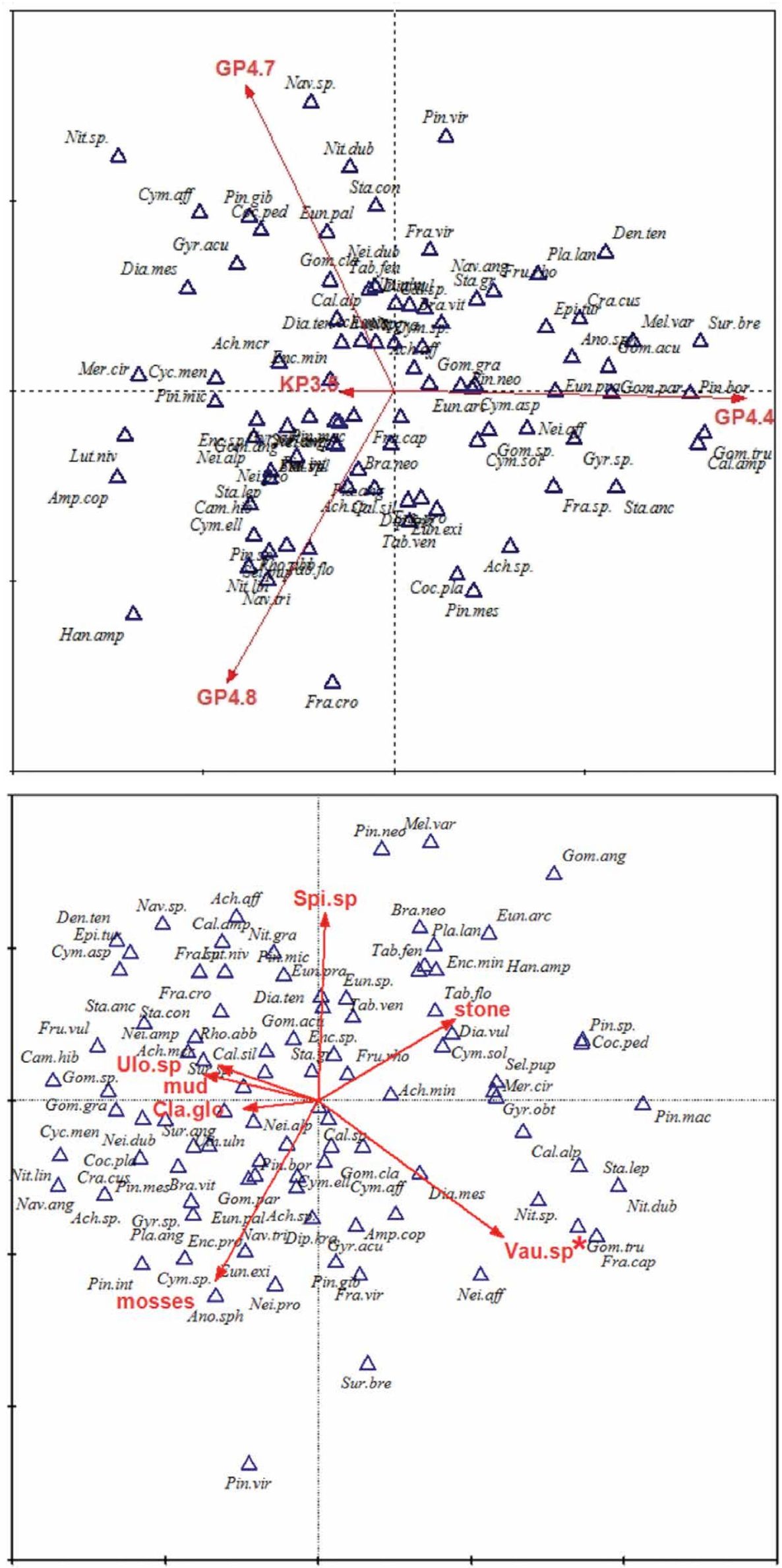

Figure 7. Canonical variates analysis (CVA) of diatoms species composition was done on four sites (GP4.4, GP4.7, GP4.8, KP3.5). The differentiation along the 1st axis was not statistically significant $(F=1.08, p=0.7)$. Names of species - see abbreviations Fig. 6.
Figure 8. Canonical variates analysis (CVA) of diatoms on diversified substratum: stone, mud, mosses and filamentous algae (Cladophora glomerata - Cla. glo.; Vaucheria sp. - Vau. sp.; Ulothrix sp. - Ulo. sp.; Spirogyra sp. - Spi. sp.). Diversification along first canonical axis was statistically significant $(F=1.4, p=0.02)$. The only variable differentiating data was Vaucheria $s p$. thalli (Monte Carlo test, $p=0.03$ ). The variable marked with an asterisk explains $4.8 \%$ of the total variability. Names of species - see abbreviations, Fig. 6. 


\section{Discussion}

Although observational studies like ours limit the assessment of mechanisms, the individual and collective patterns emerging from environmental, biological and spatial factors, and their shared variance, provided us with further detailed insight into what factors determine the structure of diatom assemblages in the karst water streams of the Slovak Karst. The inclusion of the biological component was particularly relevant. It helped to increase our understanding of the potential role of biological interactions at the microhabitats scale in karstic streams, for which our current knowledge is still limited. Studies on diatom biodiversity in the karst water streams of Slovak Karst are important because these microhabitats are considered to be more sensitive toward the structure of the substrate than the typical streams (Cantonati, 1998; Poulíčková et al., 2004; Buczkó, 2006). According to our knowledge, there are not many studies about karst phenomena and photosynthetic organisms. The indices of biotic integrity in this study revealed high species richness, diversity, and balanced distribution of the diatom species assemblages. The composition of natural karst water streams is related to factors such as the weathering resistance of carbonate rocks, reflected mainly in total mineral content (Wojtal and Sobczyk, 2012).

Generally, it is important to recognize the substrate and to understand mechanisms of tufa calcification in karst waters. Stones and filamentous algae are two of the most common substrates in fast-running waters, which are rare in the karstic areas. In our two karst streams in central-eastern Slovakia, macroalgae, such as Cladophora, Vaucheria, Ulothrix and Spirogyra, were relevant substrates for development of diatom assemblages, compared to the results of Wojtal and Sobczyk (2012), suggesting that two kinds of strata, epilithic and bryophytic, influenced the diatom assemblages and could provide data useful for water-quality monitoring. Barbiero (2000) observed epilithic diatoms on natural and artificial substrates and determined that the differences between the substrates were insignificant.

Diatom assemblages in karst water streams were dominated by Pinnularia, Gomphonema and Achnanthidium species. The widespread distribution of adnate species Achnanthidium minutissimum and A. pyrenaicum may indicate the importance of the physical environment in controlling biotic assemblages (Weilhoefer and Pan, 2006). Achnanthidium minutissimum, found in two karst water streams, is considered to represent a benthic periphytic habitat, however it has also been reported as tychoplanktonic or planktonic (Ehrlich, 1995). Krammer and Lange-Bertalot (1991) and Poulíčková et al. (2017) noted that $A$. minutissimum is one of the most frequently occurring diatoms in freshwater benthic samples. This species was reported from alkaline and acidic, oligotrophic and hypertrophic waters, and its apparent ubiquity is puzzling; and therefore, sometimes questioned (Round et al., 1990). Potapova and Hamilton (2007) concluded from SEM observations that ultrastructural characters do not discriminate among taxa within the Achnanthidium minutissimum complex.

The relatively large species richness generally confirms the findings of other studies carried out in the Wyżyna Krakowsko-Częstochowska Upland (Poland). This karst is formed in Upper Jurassic calcareous rock, where Wojtal (2009) described 307 taxa from Kobylanka stream, while Kawecka (2012) found 414 species in 27 karst streams in the Tatra National Park. The karst springs diatom epilithic assemblages in Bosnia and Herzegovina were studied by Dedić et al. (2015). Lai et al. (2016) also noted epilithic diatom assemblages in a karst spring of Sardinia (Italy) and confirmed ecological potential of the karst features. In relation to trophy, diatoms of a wide ecological spectrum, from oligo- to eutrophic, were most frequent in the typical streams but rare in the karst streams. Diatoms are a significant constituent of epilithic assemblages in karst water streams of central-eastern Slovakia.

Our studies contribute to improving the knowledge of the diatoms in the Slovak Karst and suggested that all kinds of substrates can be successfully inhabited by diatoms. Hall and Smol (1999) mentioned that the diatom assemblages on various substrates become uniform in meso- and eutrophic waters, where there is nutrient limitation. The general variability of the karstic streams environment in central-eastern Slovakia play a very important role in determining the distribution of diatoms. In all cases, our study showed that diatom assemblages in karst water streams of the Slovak Karst required ecological monitoring. However, spatial gradients were also evident over these relatively small microhabitats, which may reflect high dispersal effects, although biotic factors have largely been overlooked in karst water stream studies at similar or larger spatial scales. Our data offered that it seems to be crucial to assess an effect of biotic factors on diatom assemblage structure in addition to environmental and spatial indicators. On the other hand, we could risk underestimating the total conservation of these diatom assemblages.

\section{Conclusions}

In two nameless karstic streams of the Slovak Karst (Krásnohorská Dlhá Lúka Village and Gombasek Cottage Settlement), 124 species on seven substrates, such as stones, mud, submerged mosses and filamentous algae, i.e., Cladophora glomerata, Vaucheria sp., Ulothrix zonata, and Spirogyra sp., were observed. Both species richness and Shannon-Wiener indices showed congruent biotic integrity. The diatom assemblages were mostly structured by environmental factors, calcium and $\mathrm{pH}$ gradients, confirmed by canonical variates analysis (CVA) and Monte Carlo permutation tests. The unique spatial and biological gradients, specific to different guilds related to each other, were also evident. The Slovak karstic streams should be especially protected and regularly monitored. 


\section{Acknowledgments}

The authors wish to express their gratitude to Anna Wojciechowska for statistical comments. We also thank two reviewers for valuable comments on the manuscript. This research was supported by the National Science Centre under Grant N N307 600640.

\section{References}

Aboal, M., Prefasi, M. and Asencio, M.D., 1996, The aquatic microphytes and macrophytes of the Transvase Tajo-Segura irrigation system, southeastern Spain: Hydrobiology, v. 340, no. 1-3, p. 101-107.

Arp, G., Bissett, A., Brinkmann, N., Cousin, S., de Beer, D., Friedl, T., Mohr, K., Neu, T.R., Reimer, A., Shiraishi, F., Stackebrandt, E. and Zippel, B., 2010, Tufa-forming biofilms of German karstwater streams: microorganisms, exopolymers, hydrochemistry and calcification, in Rogerson, M. and Pedly, M.M., eds., Tufas and Speleotherms: Unravelling the Microbial and Physical Controls: Geological Society, London, Special Publication, v. 336, p. 83-118. https://doi.org/10.1144/SP336.6.

Barbiero, R.P., 2000, A multi-lake comparison of epilithic diatom communities on natural and artificial substrates: Hydrobiology, v. 438 , p. $157-170$.

Bellinger, B.J., Cocquyt, Ch. and O'Reilly, Ch.M., 2006, Benthic diatoms as indicators of eutrophication in tropical streams: Hydrobiology, v. 573, p. 75-87. https://doi.org/10.1007/s10750-006-0262-5.

Brinkmann, R. and Parise, M., 2012, Karst environments: problems, management, human impacts, and sustainability an introduction to the special issue: Journal of Cave and Karst Studies, v. 7, p. 135-136. https://doi.org/10.4311/2011JCKS0253.

Buczkó, K., 2007, The occurrence of the epiphytic diatom Lemnicola hungarica on different European Lemnaceae species: Fottea, v. 7, p. 77-84. https://doi.org/10.5507/fot.2007.007

Cantonati, M., 1998, Diatom communities of springs in the southern Alps: Diatom Research, v. 13, p. 210-220.

Dedić, A., Plenković-Moraj, A., Borojević, K.K. and Hafner, D., 2015, The first report on periphytic diatoms on artificial and natural substrate in the karstic spring Bunica, Bosnia and Herzegovina: Acta Botanica Croatia, v. 74, no. 2, p. 393-406.

Ehrlich, A., 1995, Atlas of the Inland-Water Diatom Flora of Israel: Israel Academy of Sciences and Humanities, Jerusalem.

Ford, D.C. and Williams, P., 2007, Karst Hydrology and Geomorphology: John Wiley and Sons, Chichester, UK.

Gradziński, M., Hercman, H., Jaśkiewicz, M. and Szczurek, S., 2013, Holocene tufa in the Slovak Karst: facies, sedimentary environments and depositional history: Geological Quarterly, v. 57, p. 769-788.

Hall, R.I. and Smol, J.P., 1999, Diatoms as indicators of lake eutrophication, in: Stoermer, E.F. and Smol, J.P., eds., The Diatoms: Applications for the Environmental and Earth Sciences: Cambridge University Press, Cambridge, p. 128-168.

Hammer, Ø., Harper, D.A.T. and Ryan, P.D., 2001, Past: paleontological statistics software package for education and data analysis: Palaeontologia Electronica, v. 4 no. 1, p. 1-9.

Heino, J., Bini, L.M., Karjalainen, S.M., Mykrä, H., Soininen, J., Vieira, L.C.G. and Diniz-Filho, J.A.F., 2010, Geographical patterns of micro-organismal community structure: are diatoms ubiquitously distributed across boreal streams? Oikos, v. 119, p. 129-137. https://doi/10.1111 /j.1600-0706.2009.17778.

Kawecka, B., 2012, Diatom diversity in streams of the Tatra National Park (Poland) as indicator of environmental conditions: W. Szafer Institute of Botany, Polish Academy of Sciences, Kraków.

Kilík, J., 2008, Calcareous tufa in Slovak Karst: Naturae Tutela, v. 12, p. 177-184.

Krammer, K., 2002, Cymbella, in Lange-Bertalot, H., ed., Diatoms of Europe 3, A.R.G. Gantner Verlag K.G. Ruggell, p. 31-89.

Krammer, K. and Lange-Bertalot, H., 1986, Bacillariophceae. 1. Naviculaveae, in Ettl, H., Gerloff, J., Heyning, H. and Mollenhauer, D., eds., Süßwasserflora von Mitteleuropa, 2/1: Gustav Fischer Verlag, Stuttgart, p. 759.

Krammer, K. and Lange-Bertalot, H., 1991, Bacillariophceae. 4. Achnanthaceae, Kritische Ergänzungen zu Navicula (Lineolatae) und Gomphonema, Gesamtliteraturverzeichnis Teil 1-4, in: Ettl, H., Gerloff, J., Heyning, H. and Mollenhauer, D., eds., Süßwasserflora von Mitteleuropa 2/4: Gustav Fischer Verlag, Stuttgart., p. 554.

Krammer, K. and Lange-Bertalot, H., 2004, Bacillariophceae. 3. Centrales, Fragilariaceae, Eunotiaceae, in: Ettl, H., Gerloff, J., Heyning, H. and Mollenhauer, D., eds., Süßwasserflora von Mitteleuropa 2/3, Spektrum Akademischer Verlag Heidelberg, Berlin, p. 345.

Lai, G., Padedda, B.M., Wetzel, C.E., Luglié, A., Sechi, N. and Ector, L., 2016, Epilithic diatom assemblages and environmental quality of the Su Gologone karst spring (central-eastern Sardinia, Italy): Acta Botanica Croatica, v. 75, no. 1, p. 129-143. https://doi/10.1515/botcro-2016-0008.

Lange-Bertalot, H., 2001, Navicula sensu stricto. 10 genera separated from Navicula sensu lato. Frustulia, in: Lange-Bertalot, H., ed., Diatoms of Europe 2, A.R.G. Gantner Verlag K.G. Ruggell.

Lange-Bertalot, H. and Wojtal, A.Z., 2014, Diversity in species complexes of Placoneis clementis (Grunow) Cox and Paraplaconeis placentula (Ehrenberg) Kulikovskiy, Lange-Bertalot and Metzeltin: Nova Hedwigia, v. 143, p. 403-420.

Potapova, M., Charles, D.F., Ponander, K.C. and Winter, D.M., 2004, Quantifying species indicator values for trophic diatom indices: A comparison of approaches: Hydrobiology, v. 517, p. 25-41.

Potapova, M. and Hamilton, P.B., 2007, Morphological and ecological variation within the Achnanthidium minutissimum (Bacillariophyceae) species complex: Journal of Phycology, v. 43, p. 561-575. https://doi/10.1111/j.1529-8817.2007.00332.

Poulíčková, A., Hájková, P., Krenková, P. and Hájek, M., 2004, Distribution of diatoms and bryophytes on linear transect through spring fens: Nova Hedwigia, v. 78, p. 411-424.

Pouličková, A., Letáková, M., Hašler, P., Cox, E. and Duchoslav M., 2017, Species complexes within epiphytic diatoms and their relevance for the bioindication of trophic status: Science of The Total Environment, v. 599-600, p. 820-833. https://doi.org/10.1016/j.scitotenv.2017.05.034.

Round, F.E., Crawford, R.M. and Mann, D.G., 1990, The diatoms. Biology and morphology of the genera: Cambridge University Press, Cambridge.

Smol, J.P. and Stoermer, E.F., 2015, The Diatoms: Applications for the Environmental and Earth Sciences: $2^{\text {nd }}$ Ed, Cambridge University Press, Cambridge.

ter Braak, C.J.F. and Šmilauer, P., 2002, CANOCO reference manual and CanoDraw for Windows user's guide: software for canonical community ordination (version 4.5): Biometrics, Wageningen and Česke Budéjovice.

Van Dam, H., Mertens, A. and Sinkeldam, J., 1994, A coded checklist and ecological indicator values of freshwater diatoms from the Netherlands: Netherlands Journal of Aquatic Ecology, v. 28, no. 1, p. 117-133.

Weilhoefer, Ch.L. and Pan, Y., 2006, Diatom assemblages and their associations with environmental variables in Oregon Coast Range streams, USA: Hydrobiology, v. 561, p. 207-219. https://doi.org/10.1007/1-4020-5070-4_15.

White, W.B., 1988, Geomorphology and Hydrology of Karst Terrains: University Press, New York, Oxford.

Wojtal, A.Z., 2009, The diatoms of Kobylanka stream near Kraków (Wyżyna Krakowsko-Częstochowska Upland, S Poland): Polish Botanical Journal, v. 54, no. 2, p. 129-330.

Wojtal, A.Z. and Sobczyk, Ł., 2012, The influence of substrates and physicochemical factors on the composition of diatom assemblages in karst springs and their applicability in water-quality assessment: Hydrobiology, v. 695, p. 97-108. 